\title{
Spatial relationships of ovarian follicles and luteal structures in dairy cows subjected to ovulation synchronization: Progesterone and risks for luteolysis, ovulation, and pregnancy
}

\section{J. S. Stevenson*}

Department of Animal Sciences and Industry, Kansas State University, Manhattan 66506-0201

\section{ABSTRACT}

Objectives were to determine relative ovary location of follicles, GnRH-induced corpora lutea (CL), and older CL present in ovaries as part of ovulation synchronization and their associations with progesterone concentration and risk for luteolysis, ovulation, and pregnancy. Cows were exposed to a timed artificial insemination (AI) program [GnRH-1-7 d- PGF $_{2 \alpha}$ (1 dose or 2 doses $24 \mathrm{~h}$ apart) $-56 \mathrm{~h}$ after first or only dose of $\mathrm{PGF}_{2 \alpha}-\mathrm{GnRH}-2-16 \mathrm{~h}$-timed AI at $72 \pm 3 \mathrm{~d}$ in milk]. Blood was collected to assess progesterone when ovarian structures were mapped in 694 cows before GnRH-1 and before and $48 \mathrm{~h}$ after $\mathrm{PGF}_{2 \alpha}$ and, in a subset of cows, size of CL $(\mathrm{n}=599)$ and progesterone $(\mathrm{n}=380)$ at $6 \mathrm{~d}$ after AI. Dominant follicles and CL in singleovulating cows were detected more often in right than left ovaries (follicles before GnRH-1: $60.6 \%$ right and GnRH-2: $61.2 \%$ right; and CL before GnRH-1: $58.6 \%$ right and GnRH-2: $66.4 \%$ right). Dominant follicles in single-ovulating cows before GnRH-1 tended to be ipsilateral to the CL more often than contralateral (54.8 vs. $45.2 \%$ ) with co-dominant follicles identified in both ovaries (19.3\%). In response to GnRH-1 or GnRH-2, more left-ovary follicles ovulated contralateral to CL (left to right, 54.7\%; right to left, $34.7 \%$ ) than rightovary follicles, but fewer left-ovary follicles ovulated ipsilateral to CL (left to left: $45.3 \%$ ) than right-ovary follicles ovulated ipsilateral (right to right: 65.3\%). Preovulatory follicles in single-ovulating cows before $\mathrm{PGF}_{2 \alpha}$ tended to be detected more often ipsilateral than contralateral to CL induced by GnRH-1 (younger CL; 56.5 vs. $43.6 \%$ ), but were of equal frequency ipsilateral or contralateral to older CL present before GnRH-1. Luteolytic risk was less in cows bearing co-dominant follicles in both ovaries compared with those in either right or left ovaries. Luteolytic risk in single-ovulating

Received November 22, 2018.

Accepted February 15, 2019.

*Corresponding author: jss@ksu.edu cows did not differ between ovaries. Luteolytic risk was greater for cows bearing older CL $(86.5 \%)$ than for cows bearing younger GnRH-1-induced CL (65.3\%) or both $(79.6 \%)$. Pregnancy risk at $60 \mathrm{~d}$ after AI was or tended to be greater in cows having both CL types compared with either younger or older CL, respectively, partly because of greater embryonic loss in the latter 2 cases. More female calves tended to be carried in right horns when conception occurred after first service, whereas the opposite greater female frequency occurred in left horns after repeat services. Right-ovary dominance is evident before and after GnRH treatment.

Key words: ovary dominance, ovulation synchronization, luteolytic risk, fertility

\section{INTRODUCTION}

Ovaries in most domestic farm animals do not function equally during the estrous cycle; one of the ovaries is more active than the other. Ovulation occurs more frequently from right than left ovaries, varying from 54 to $60 \%$ in ewes and goats and from 60 to $65 \%$ in cows (Pineda, 1989). In contrast, the left ovary in the sow is more functional, producing 55 to $60 \%$ of the oocytes, and the mare ovulates approximately $60 \%$ of the oocytes from the left ovary (Pineda, 1989). Explanations for right-dominated ovulations in ruminants have included the proximity of the left ovary to the rumen and other extrinsic factors such as temperature or pressure fluctuations and mechanical contractions of the rumen (Pineda, 1989). It is not clear, however, whether any intrinsic factors play a role.

Relative ovarian location of preovulatory follicles and corpora lutea (CL) resulted in shorter interovulatory intervals when follicle and CL were in the same (ipsilateral) ovary than when in the contralateral ovary in spontaneously cycling heifers but not in mares (Ginther et al., 2013). In cattle, positive CL-follicle intra-ovarian relationships during the estrous cycle have been found in several studies (Matton et al., 1981; Maurasse et al., 1985; Pierson and Ginther, 1987) but not all (Ireland et al., 1979; Ginther et al., 1989). 
No information, however, is known about the spatial relationship of ovarian follicles and CL and subsequent risks for ovulation, luteolysis, or pregnancy during the estrous cycle when GnRH treatments are applied to accomplish synchronization of ovulation before timed AI. For example, do younger GnRH-induced CL regress at different rates in the presence or absence of an older CL or because of their different spatial relationship to the dominant or preovulatory follicle? Do follicles in the left or right ovary respond differently to GnRHinduced LH secretion to form CL when ipsilateral or contralateral to a younger or older CL?

The process of CL death includes both functional luteolysis (decrease in progesterone concentration in the blood) and structural luteolysis (involution of the CL in the ovary to form a corpus albicans; McCracken, 1998). The mechanism of luteolysis that requires an intact uterine horn ipsilateral to the ovary-bearing CL was demonstrated by elegant surgical manipulations of uterine horns and their utero-ovarian vasculature responsible for the local transfer of a uterine-derived substance (now accepted to be $\mathrm{PGF}_{2 \alpha}$ ) to the ovarybearing ovarian artery in domestic farm species (Ginther, 1976). The CL becomes responsive to exogenous $\mathrm{PGF}_{2 \alpha}$ treatment as early as $\mathrm{d} 4$ or 5 after ovulation, with CL $<10 \mathrm{~d}$ old being more resistant to complete regression after a single standard dose of $\mathrm{PGF}_{2 \alpha}$ than older CL (Momont and Seguin, 1984). New CL formed after GnRH treatment during the estrous cycle had greater luteolytic risk after $\mathrm{PGF}_{2 \alpha}$ in the presence of older CL than in cows bearing only a new CL (Stevenson, 2016a). Ovarian follicles forming either new CL or luteinized follicles in response to human chorionic gonadotropin (hCG) treatment in heifers on d 10 of the estrous cycle were responsive to $\mathrm{PGF}_{2 \alpha}$ when less than $5 \mathrm{~d}$ old if they were in the presence of older CL (Howard and Britt, 1990).

Hypotheses to test included: (1) a greater proportion of ovarian structures (dominant or preovulatory follicles and older or GnRH-induced younger CL) will be identified in the right compared with the left ovary; (2) the relative ratio of right to left ovary-bearing CL will be altered after exposure to $\mathrm{GnRH}$ as well as a greater frequency of right horn pregnancies; (3) younger, GnRH-induced CL found ipsilateral to older CL will have greater luteolytic risk than those contralateral to older CL; and (4) spatial and relative location of dominant or co-dominant follicles before AI will not affect ovarian characteristics and subsequent risks of ovulation and pregnancy.

Objectives were to determine various outcomes (changes in dominant follicle size, progesterone concentration, and risks for luteolysis, ovulation, and pregnancy) in lactating dairy cows subjected to ovulation synchronization that were associated with (1) the absolute and relative spatial location of ovarian structures before and after exposure to GnRH, and resulting right or left-horn pregnancies; (2) the ovary location of preovulatory follicles and their relative location to GnRH-induced younger and older CL present before GnRH; and (3) the luteal environment (new CL, older CL, or both) at the time of $\mathrm{PGF}_{2 \alpha}$.

\section{MATERIALS AND METHODS}

\section{Source of Data}

Maps of ovarian structures constructed previously in 4 studies (Stevenson et al., 2012; Pulley et al., 2015; Stevenson, 2016b; Stevenson et al., 2018) were re-examined to determine ovarian spatial locations of dominant and preovulatory follicles relative to older and younger GnRH-induced luteal structures identified before and during exposure of 694 primiparous and multiparous lactating Holstein cows to a standard 7-d timed AI program [GnRH-1-7 d-PGF $2 \alpha$ (1 dose or 2 doses $24 \mathrm{~h}$ apart) $-56 \mathrm{~h}$ after first or only dose of $\mathrm{PGF}_{2 \alpha}-$ GnRH-2-16 h-timed AI at $72 \pm 3 \mathrm{~d}$ in milk] before first postpartum AI. In one study (Stevenson et al., 2018), some cows received either one 50-mg dose of $\mathrm{PGF}_{2 \alpha}$ (dinoprost tromethamine, Zoetis Inc., Kalamazoo, MI) or two 25-mg doses of $\mathrm{PGF}_{2 \alpha}$ administered 24 $\mathrm{h}$ apart; otherwise, cows received 1 standard 25-mg dose of $\mathrm{PGF}_{2 \alpha}$. In that same study (Stevenson et al., 2018), data from cows exposed to a 5-d Ovsynch timed AI program, regardless of $\mathrm{PGF}_{2 \alpha}$ dose-frequency, were not included in the present study. In each of the 4 studies, estrous cycles were presynchronized with either 2 doses of $\mathrm{PGF}_{2 \alpha}$ administered $14 \mathrm{~d}$ apart (the last of which was administered 10 or $11 \mathrm{~d}$ before initiating Ovsynch; Pulley et al., 2015; Stevenson, 2016b) or presynchronization combinations of $\mathrm{GnRH}$ and $\mathrm{PGF}_{2 \alpha}\left[\mathrm{PGF}_{2 \alpha}\right.$ and GnRH administered 10 and $7 \mathrm{~d}$ before Ovsynch (Stevenson et al., 2012; Stevenson, 2016b; Stevenson et al., 2018) or GnRH and $\mathrm{PGF}_{2 \alpha}$ administered 18 and 11 d before Ovsynch, respectively; Stevenson, 2016b].

\section{Data Collection}

Before GnRH-1 and at 0 and $48 \mathrm{~h}$ after $\mathrm{PGF}_{2 \alpha}$ (first or only treatment of $\mathrm{PGF}_{2 \alpha}$ ), ovaries were scanned by transrectal ultrasonography $(7.5-\mathrm{MHz}$ linear-array transducer, Aloka 500V; Corometrics Medical Systems Inc., Wallingford, CT) and all ovarian follicles $>5 \mathrm{~mm}$ were sized by electronic calipers and mapped relative to location of CL. Ovulation (single or multiple) was 
determined by disappearance of follicles previously mapped and recorded either 6 or $7 \mathrm{~d}$ after $\mathrm{GnRH}$ treatments. Frozen images of follicles and CL were assessed using electronic calipers and measuring diameters in 2 directions perpendicular to one another. Total volume of luteal tissue was calculated $\left[4 / 3 \times \mathrm{r}^{3} \times \pi\right.$, where $\mathrm{W}$ = largest width and $\mathrm{H}=$ largest height of the structure; $\mathrm{r}=\operatorname{radius}(\mathrm{W} / 2+\mathrm{H} / 2) / 2$, and $\pi=3.14159]$. When a luteal structure contained a fluid-filled cavity, the volume of the cavity was subtracted from the total luteal volume.

Blood samples were collected by caudal vessel puncture at GnRH-1 and 0 and $48 \mathrm{~h}$ after $\mathrm{PGF}_{2 \alpha}$. In 3 of the 4 studies, post-AI luteal volume $(\mathrm{n}=599)$ and blood $(\mathrm{n}=380)$ were collected on d 6 after timed AI for subsequent progesterone analyses. Complete details of ovarian scans, ovulation detection, blood sera processing, and radioimmunoassay details are documented in the 4 reports (Stevenson et al., 2012; Pulley et al., 2015; Stevenson, 2016b; Stevenson et al., 2018).

Ovary location of each dominant and preovulatory follicle was determined [right, left, or both (only when co-dominant follicles ovulated)] and their spatial location (ipsilateral, contralateral, or both) relative to CL identified and present before GnRH-1 (defined as older CL that were at least $7 \mathrm{~d}$ old but most likely 10 to $14 \mathrm{~d}$ old at the time of $\mathrm{PGF}_{2 \alpha}$ treatment) or relative to new younger CL formed after treatment with GnRH-1 (approximately $5 \mathrm{~d}$ old at the time of $\mathrm{PGF}_{2 \alpha}$ treatment). Co-dominant follicles were verified by post-ovulatory examinations of a newly revealed CL (multiple ovulation) located on the ovarian map previously occupied by dominant follicle(s).

\section{Statistical Analyses}

Discrete binomial outcomes (risks of ovulation and pregnancy, and proportions of cows having progesterone concentrations $<0.5 \mathrm{ng} / \mathrm{mL}$ ) were analyzed by procedure GLIMMIX (Enterprise 6.1, SAS Institute Inc., Cary, NC). Options used in the model statement included LINK $=$ LOGIT, DIST $=$ BINOMIAL, and the least squares means option of ILINK and DIFF. Continuous outcome variables were analyzed by ANOVA using procedure GLM in SAS. Multinomial data (number of CL) were analyzed in procedure GLIMMIX with DIST $=$ MULTINOMIAL and least squares means were estimated in procedure MIXED with DDFM = SATTERTHWAITE option in the model statement to adjust the degrees of freedom for the unequal variances observed in the number of CL.

Parity significantly affected progesterone concentrations (means of 0.2 to $0.4 \mathrm{ng} / \mathrm{mL}$ greater for primipa- rous than multiparous cows) and number of CL (means of $0.2 \mathrm{CL}$ greater for multiparous than primiparous cows) as reported in the original published papers. Right-left ovary proportions were affected only slightly by parity. Parity was included in the GLIMMIX and ANOVA models when it was $P<0.10$ so least squares means were adjusted appropriately; otherwise, parity was excluded from models.

To determine various proportions of follicles or CL in ovaries and proportions of ovarian structure locations (right, left, ipsilateral, or contralateral) in single-ovulating cows, a z-statistic was applied (MedCalc; https: //www.medcalc.org/calc/) to test a null hypothesis of $50 \%$ (i.e., that proportions differed from the expected $50 \%$ from either ovary or development of dominant or preovulatory follicles differed from $50 \%$ relative to younger or older CL categories). Comparisons of singleovulating cows with left or right ovary (or ipsilateral or contralateral) frequencies were not compared with multiple-ovulating cows because of the small frequency of multiple ovulations relative to single ovulations from either right or left ovaries.

Outcomes of interest to meet objective 1 included absolute and relative location of ovarian structures associated with diameters of dominant and preovulatory follicles, subsequent ovulation risk, number of CL, and progesterone concentration before $\mathrm{GnRH}-1$ and $\mathrm{PGF}_{2 \alpha}$ treatments and at $48 \mathrm{~h}$ after $\mathrm{PGF}_{2 \alpha}$. Logistic regression applied to binomial ovulation risk (separate analysis for GnRH-1 and GnRH-2) with ovary location (right, left, or both; or ipsilateral, contralateral, or both) as fixed effects. A general linear model (procedure GLM in SAS) was used to analyze continuous variables (progesterone concentration, number of CL, and follicle diameter) by applying the same previously described fixed effects. In addition, location of the dominant follicle relative to the CL before GnRH-1 (ipsilateral, contralateral, or both) was a fixed effect in a separate model to determine its association with progesterone concentration, number of CL, dominant follicle diameter, and ovulation risk. Log-transformations of data were made when multinomial distributions failed normality (i.e., CL numbers).

Analyses to meet objective 2 included determining the ovarian relationship of the preovulatory follicle relative to the GnRH-induced (younger) or older CL, progesterone concentration, and preovulatory follicle diameter $48 \mathrm{~h}$ after $\mathrm{PGF}_{2 \alpha}$ treatment of Ovsynch and subsequent ovulation risk after GnRH-2 of Ovsynch. Location of preovulatory follicles was a fixed effect (ipsilateral, contralateral, or both) to determine its association with progesterone concentration, follicle diameter, and ovulation risk. 
A second analysis determined the influence of the ovarian location of the preovulatory follicles. Location of preovulatory follicles as fixed effects was defined as 1 follicle in either left or right ovaries (left $\times 1$ or right $\times 1)$; 2 or more co-dominant follicles in either left or right ovaries (left $\times 2$ or right $\times 2$ ); or 2 or more codominant follicles with 1 in each ovary (left $\times 1+$ right $\times 1$ ). Cows categorized with 2 or more co-dominant follicles were only included when it was determined that they ovulated after GnRH-2. Continuous dependent variables including number of CL, follicle diameter, and progesterone concentration were analyzed by ANOVA as previously described with the same fixed independent effects described for the discrete binomial variables.

Because trans-uterine migration is absent in inseminated cattle (Scanlon, 1972; i.e., non-embryo-transfer recipient cows), the site of pregnancy should indicate from which ovary the oocyte was produced. To determine whether right or left ovary-derived pregnancies resulted in sex/horn differences of calves born, data were collected from 4 other studies conducted earlier in Holstein cows located in the Kansas State University Dairy Teaching and Research Center. These data were appended to the data described previously. Additional observations originated from cows diagnosed not pregnant at 30 to $36 \mathrm{~d}$ since last AI. Cows were exposed to a Resynch Ovsynch timed AI program for reinsemination. Information from all studies included CL side of a single conception (i.e., horn carrying the calf), sex of calf born, gestation duration, and DIM at conception. Sex of calf $(0=$ male and $1=$ female $)$ was the dependent variable logistically regressed (procedure GLIMMIX) on the fixed effects of service number (first vs. repeat AI), uterine horn (right vs. left), their interaction, and parity (primiparous vs. multiparous). Gestation duration was analyzed by procedure GLM using the same model variables.

To meet objective 3 , various characteristics at the time of $\mathrm{PGF}_{2 \alpha}$ treatment (concentrations of progesterone at 0 and $48 \mathrm{~h}$ after $\mathrm{PGF}_{2 \alpha}$ treatment and preovulatory follicle diameter) were analyzed by ANOVA as previously described. The model included the fixed effects of $3 \mathrm{CL}$ age classes (new younger GnRH-induced CL, older CL, or both CL types at the time of $\mathrm{PGF}_{2 \alpha}$ treatment). Logistic regression to assess risks of luteolysis, ovulation, and pregnancy at d 32 and 60 after AI was applied with a model that included the fixed effects of CL age class. Only cows having functional CL (progesterone $>1 \mathrm{ng} / \mathrm{mL}$ before the first or only $\mathrm{PGF}_{2 \alpha}$ treatment) were included in these analyses. Risk of luteolysis in those cows was defined as the proportion of cows with concentrations of progesterone $<0.5 \mathrm{ng} / \mathrm{mL}$
$48 \mathrm{~h}$ after $\mathrm{PGF}_{2 \alpha}$ treatment. Complete luteolysis defined by progesterone $<0.3$ to $0.5 \mathrm{ng} / \mathrm{mL}$ at the time of AI was not possible because in only 1 study were blood samples collected before timed $\mathrm{AI}$ at $72 \mathrm{~h}$ after $\mathrm{PGF}_{2 \alpha}$.

Data are presented as least squares means \pm standard errors where appropriate or as mean percentages or proportions. Differences among dependent variables were considered significant when $P \leq 0.05$, whereas differences between $0.05<P \leq 0.15$ are reported as tendencies. Means were separated by the least significant difference test of procedure GLM in SAS or by $t$-test in procedure GLIMMIX when protected by significant $F$-tests.

\section{RESULTS}

\section{Ovary Location of Follicles}

Frequency of dominant follicles in the right ovary was greater $(P \leq 0.05)$ than that in the left ovary before both GnRH treatments of the Ovsynch timed AI program (Table 1). The proportion of dominant follicles in single-ovulating cows in right ovaries (60.6 vs. $61.2 \%$ ), in left ovaries (39.4 vs. $38.8 \%$ ), or proportion of codominant follicles in both ovaries (4.5 vs. 9.1\%) did not change from after GnRH-1 to before GnRH-2 (Table 1). These proportions were not associated with any difference in ovulation risk between ovaries after GnRH-1 (Table 1). When a single dominant follicle was in the right ovary before GnRH-2, frequency of ovulation after GnRH-2 tended $(P=0.06)$ to be greater (95.1 vs. $91.3 \%$ ) than when a single dominant follicle was in the left ovary. The right ovary bore preovulatory follicles more frequently than the left ovary [both differed $(P$ $\leq 0.05)$ from $50 \%$; Table 1], and more than $90 \%$ of the ovulations were single ovulations from either the left or right ovary. In contrast, for cows with multiple ovulation, $58.7 \%$ of the co-dominant follicles were either both in the right ovary or both in the left ovary, whereas the remaining $(41.3 \%)$ were detected in both ovaries. Neither diameter of the dominant follicles, number of CL per cow, nor progesterone concentration before GnRH-1 or at $48 \mathrm{~h}$ after $\mathrm{PGF}_{2 \alpha}$ ( $8 \mathrm{~h}$ before GnRH-2) differed between ovaries bearing a single dominant follicle before either GnRH treatment (data not shown).

Location of preovulatory follicles (verified before and after subsequent ovulation) was categorized as singleovulating follicles in either ovary (left $\times 1$ or right $\times$ 1 ), co-dominant multiple-ovulating follicles in the left or right ovary (left $\times 2$ or right $\times 2$ ), or co-dominant follicles, at least one in each ovary (left $\times 1+$ right $\times 1)$. Although number of CL per cow did not differ, cows bearing co-dominant follicles in either the right, 
Table 1. Ovary location of the dominant follicle (DF) and subsequent ovulation risk to $\mathrm{GnRH}$ treatments during the Ovsynch timed AI program

\begin{tabular}{lccc}
\hline Timing and ovary & $\begin{array}{c}\text { Cows } \\
(\text { no. })\end{array}$ & $\begin{array}{c}\text { DF location } \\
(\%)\end{array}$ & $\begin{array}{c}\text { Ovulation } \\
\text { risk }(\%)\end{array}$ \\
\hline $\begin{array}{l}\text { Before GnRH-1 } \\
\text { (onset of Ovsynch) }\end{array}$ & & & \\
Left & 261 & $37.7(39.4)$ & $67.5^{\mathrm{a}}$ \\
Right & 401 & $57.9(60.6)$ & $67.0^{\mathrm{a}}$ \\
Both & 31 & 4.5 & $100^{\mathrm{b}}$ \\
Before GnRH-2 & & & \\
(end of Ovsynch) & & & \\
Left & 245 & $35.3(38.8)$ & $91.4^{\mathrm{A}}$ \\
Right & 386 & $55.6(61.2)$ & $95.1^{\mathrm{B}}$ \\
Both & 63 & 9.1 & $98.4^{\mathrm{B}}$ \\
\hline
\end{tabular}

${ }_{\mathrm{a}, \mathrm{b}}$ Means within column and GnRH treatment differ $(P \leq 0.05)$.

${ }^{\mathrm{A}, \mathrm{B}}$ Means within column and $\mathrm{GnRH}$ treatment tended to differ $(P \leq$ $0.10)$.

${ }^{1}$ Proportions in parentheses within GnRH treatment for single-ovulating cows differ from $50 \%(P \leq 0.05)$ by applying a z-statistic with a null hypothesis of $50 \%$.

left, or both ovaries before $\mathrm{PGF}_{2 \alpha}$ treatment were exposed to lesser progesterone concentrations than cows bearing only 1 dominant follicle (Table 2). Although the concentration of progesterone did not differ among $\mathrm{CL}$ categories by $48 \mathrm{~h}$ after $\mathrm{PGF}_{2 \alpha}$, luteolytic risk (cut point of $<0.5 \mathrm{ng} / \mathrm{mL}$ ) in cows bearing at least 2 codominant follicles (one in each ovary) was less $(P \leq$ $0.05)$ compared with cows bearing at least 2 co-dominant follicles in both ovaries or only 1 follicle in either ovary (Table 2). Resulting ovulation risk after GnRH-2 tended $(P \leq 0.10)$ to be greater in cows bearing at least 2 co-dominant follicles compared with cows having only 1 dominant follicle in the left but not the right ovary (Table 2). As expected because of multiple ovulation, volume of luteal tissue and concentration of progesterone $6 \mathrm{~d}$ after timed AI was greater $(P \leq 0.05)$ in cows bearing at least 2 co-dominant follicles that ovulated after GnRH-2 than in cows bearing but 1 dominant follicle before GnRH-2 (Table 2). Neither pregnancy per AI nor pregnancy loss was affected by location of the preovulatory follicles (data not shown).

\section{Location of Follicles Relative to Corpora Lutea}

Location of dominant follicles before GnRH-1 treatment only tended $(P=0.12)$ to be more often (differing from $50 \%$ ) ipsilateral to the CL $(54.8 \%)$ than contralateral to the CL (45.2\%; Table 3). Odds of finding co-dominant follicles in both ovaries were $19.3 \%$. As expected, fewer $(P \leq 0.05) \mathrm{CL}$ and lesser progesterone concentrations $(P \leq 0.05)$ were detected in cows in which the dominant follicle was found either ipsilateral or contralateral to the CL compared with cows in which co-dominant follicles were both ipsilateral and contralateral to the CL. Neither diameter of dominant follicles (data not shown) nor ovulation risk in response to $\mathrm{GnRH}$ differed regardless of dominant follicle location relative to the CL (Table 3).

Table 2. Characteristics of lactating dairy cows depending on the location of the preovulatory follicle(s) at the time of PGF ${ }_{2 \alpha}$ treatment during the Ovsynch timed AI program in cows with single or multiple ovulations after GnRH-2

\begin{tabular}{|c|c|c|c|c|}
\hline \multirow[b]{2}{*}{ Item } & \multicolumn{4}{|c|}{ Location of preovulatory follicle $^{1}$} \\
\hline & Left $\times 1$ & Right $\times 1$ & Left $\times 2$ or right $\times 2$ & Left $\times 1+$ right $\times 1$ \\
\hline Cows (no.) & 245 & 386 & 80 & 62 \\
\hline Corpora lutea (CL) per $\operatorname{cow}^{2}$ (no.) & $1.9 \pm 0.05^{\mathrm{a}}$ & $1.8 \pm 0.04^{\mathrm{a}}$ & $1.7 \pm 0.1^{\mathrm{a}}$ & $1.8 \pm 0.1^{\mathrm{a}}$ \\
\hline \multicolumn{5}{|l|}{ Progesterone $(\mathrm{ng} / \mathrm{mL})$} \\
\hline $\begin{array}{l}\text { Proportion of cows with progesterone } \\
<0.5 \mathrm{ng} / \mathrm{mL}^{3}(\%)\end{array}$ & $81.2^{\mathrm{a}}$ & $81.9^{\mathrm{a}}$ & $83.9^{\mathrm{a}}$ & $69.8^{\mathrm{b}}$ \\
\hline Preovulatory follicle diameter (mm) & $14.0 \pm 0.1^{\mathrm{a}}$ & $14.0 \pm 0.1^{\mathrm{a}}$ & $14.2 \pm 0.3^{\mathrm{a}}$ & $13.6 \pm 0.3^{\mathrm{a}}$ \\
\hline Ovulation risk after GnRH (\%) & $91.4^{\mathrm{A}}$ & $95.1^{\mathrm{B}}$ & $96.2^{\mathrm{B}}$ & $100^{\mathrm{B}}$ \\
\hline Post-AI luteal tissue volume ${ }^{4}\left(\mathrm{~cm}^{3}\right)$ & $5.8 \pm 0.2^{\mathrm{a}}(218)$ & $5.2 \pm 0.1^{\mathrm{a}}(356)$ & $7.8 \pm 0.4^{\mathrm{b}}(78)$ & $8.2 \pm 0.5^{\mathrm{b}}(57)$ \\
\hline Post-AI progesterone $^{4}(\mathrm{ng} / \mathrm{mL})$ & $3.0 \pm 0.1^{\mathrm{a}}(134)$ & $3.2 \pm 0.1^{\mathrm{a}}(222)$ & $4.5 \pm 0.2^{\mathrm{b}}(52)$ & $4.0 \pm 0.3^{\mathrm{b}}(45)$ \\
\hline \multicolumn{5}{|c|}{$\overline{\mathrm{a}, \mathrm{b}}$ Means within row and ovulation category differ $(P<0.05)$} \\
\hline \multicolumn{5}{|c|}{$\begin{array}{l}{ }^{1} \text { Includes all cows regardless of luteolytic or ovulation risk. Left } \times 1 \text { or right } \times 1=1 \text { preovulatory follicle on left or right ovary; left } \times 2 \text { or } \\
\text { right } \times 2=2 \text { or more co-dominant follicles on left or right ovary; left } \times 1+\operatorname{right} \times 1=1 \text { or more preovulatory follicles on both ovaries. Least } \\
\text { squares means } \pm \text { SEM where appropriate. }\end{array}$} \\
\hline \multicolumn{5}{|c|}{${ }^{2}$ Number of CL before treatment with $\mathrm{PGF}_{2 \alpha}$. } \\
\hline${ }^{3}$ At $48 \mathrm{~h}$ after $\mathrm{PGF}_{2 \alpha}$ treatment. & & & & \\
\hline
\end{tabular}


Table 3. Location of the dominant follicle (DF) relative to the corpus luteum (CL) before the time of GnRH-1 treatment (onset of Ovsynch), progesterone concentration, and subsequent ovulation risk to $\mathrm{GnRH}^{1}$

\begin{tabular}{lccccc}
\hline DF location & $\begin{array}{c}\text { Cows } \\
(\text { no. })\end{array}$ & $\begin{array}{c}\text { Frequency } \\
(\%)\end{array}$ & $\begin{array}{c}\text { CL per } \\
\text { cow (no.) }\end{array}$ & $\begin{array}{c}\text { Progesterone } \\
(\mathrm{ng} / \mathrm{mL})\end{array}$ & $\begin{array}{c}\text { Ovulation } \\
\text { risk }(\%)\end{array}$ \\
\hline Ipsilateral (I) & 258 & $44.2(54.8)$ & $1.1 \pm 0.03^{\mathrm{a}}$ & $3.9 \pm 0.1^{\mathrm{a}}$ & $65.1^{\mathrm{a}}$ \\
Contralateral (C) & 213 & $36.5(45.2)$ & $1.2 \pm 0.03^{\mathrm{a}}$ & $3.3 \pm 0.2^{\mathrm{a}}$ & $62.5^{\mathrm{a}}$ \\
I + C & 113 & 19.3 & $2.0 \pm 0.05^{\mathrm{b}}$ & $4.5 \pm 0.2^{\mathrm{b}}$ & $63.0^{\mathrm{a}}$ \\
\hline
\end{tabular}

$\overline{\mathrm{a}, \mathrm{b}}$ Means within column with different superscripts differ $(P<0.05)$.

${ }^{1}$ Least squares means \pm SEM where appropriate.

${ }^{2}$ Proportions in parentheses for single-ovulating cows did not differ from $50 \%$ ( $P=0.12$ for ipsilateral or $P=$ 0.16 for contralateral locations) by applying a z-statistic with a null hypothesis of $50 \%$.

Location of preovulatory follicles at $48 \mathrm{~h}$ after $\mathrm{PGF}_{2 \alpha}$ differed relative to the age of the CL. A tendency was found $(P \leq 0.08$; differing from $50 \%$ ) for more follicles to be found ipsilateral than contralateral to the new CL induced by GnRH-1 (56.5 vs. $43.6 \%$ ), but that relationship did not differ for location of follicles relative to older CL (52.5 vs. $47.1 \%$; Table 4) because of greater numeric proportion of preovulatory follicles detected both ipsilateral and contralateral relative to older than younger CL (21.8 vs. 15.7\%). Neither progesterone concentration at $48 \mathrm{~h}$ after $\mathrm{PGF}_{2 \alpha}$ (data not shown) nor diameter of the largest preovulatory follicle was associated with preovulatory follicle location relative to younger or older CL. Ovulation risk of preovulatory follicles was not related to their ovary location relative to new younger $\mathrm{CL}$, but ovulation risk tended $(P<$ $0.10)$ to be less when co-dominant follicles were found both ipsilateral + contralateral to older CL compared with dominant follicles located only ipsilateral to older CL (Table 4).

\section{Ovary Location of Corpora Lutea}

Frequency of finding CL in the right ovary of singleovulating cows was greater $(P \leq 0.01$; differing from $50 \%)$ than in the left ovary before and after GnRH-1 treatment (assessed before $\mathrm{PGF}_{2 \alpha}$ treatment; Table 5). The proportion of CL in either the left or right ovary decreased from before GnRH-1 to after GnRH-1 such that the proportion of cows with multiple CL detected in both ovaries doubled $(P<0.001)$ from $15.8 \%$ before GnRH-1 to $35.6 \%$ after GnRH-1 (Table 5).

Single-ovulation risk in response to GnRH-1 was less $(P<0.05)$ when CL were found in both ovaries $(54.6 \%)$ compared with cows having $1 \mathrm{CL}$ in the left $(67.3 \%)$ but not in the right ovary $(60.7 \%)$. Differences in single-ovulation risk were not detected after GnRH-2. Neither multiple-ovulation risk of preovulatory follicles in response to either GnRH-1 or GnRH-2 nor diameter of dominant follicles differed between ovaries (Table 5). As expected, before and after GnRH-1, number of CL

Table 4. Location of the preovulatory follicle (POF) relative to the GnRH-induced (younger) or older corpus luteum (CL), and POF diameter $48 \mathrm{~h}$ after $\mathrm{PGF}_{2 \alpha}$ treatment of Ovsynch and subsequent ovulation risk to GnRH-2

\begin{tabular}{lcccc}
\hline POF location & $\begin{array}{c}\text { Cows } \\
(\text { no. })\end{array}$ & $\begin{array}{c}\text { Frequency } \\
(\%)\end{array}$ & $\begin{array}{c}\text { POF diameter } \\
(\mathrm{mm})\end{array}$ & $\begin{array}{c}\text { Ovulation } \\
\text { risk }(\%)\end{array}$ \\
\hline $\begin{array}{l}\text { Younger CL } \\
\text { Ipsilateral (I) }\end{array}$ & & & & \\
Contralateral (C) & 182 & $47.6(56.5)$ & $13.9 \pm 0.2^{\mathrm{a}}$ & $94.5^{\mathrm{a}}$ \\
I + C & 140 & $36.6(43.6)$ & $13.8 \pm 0.2^{\mathrm{a}}$ & $95.0^{\mathrm{a}}$ \\
Older CL & 60 & 15.7 & $13.4 \pm 0.3^{\mathrm{a}}$ & $93.3^{\mathrm{a}}$ \\
$\quad$ Ipsilateral & & & & \\
$\quad$ Contralateral & 237 & $41.0(52.5)$ & $13.7 \pm 0.1^{\mathrm{a}}$ & $96.6^{\mathrm{A}}$ \\
I + C & 214 & $37.1(47.4)$ & $13.7 \pm 0.1^{\mathrm{a}}$ & $93.9^{\mathrm{AB}}$ \\
\hline
\end{tabular}

${ }^{a}$ Means within column and CL type with different superscripts differ $(P<0.05)$.

${ }^{\mathrm{A}, \mathrm{B}}$ Means within column and $\mathrm{CL}$ type with different superscripts tended to differ $(P \leq 0.10)$.

${ }^{1}$ Least squares means \pm SEM where appropriate.

${ }^{2}$ Proportions in parentheses within CL category for single-ovulating cows with younger CL either tended $(P=$ $0.08)$ to differ from $50 \%$ for ipsilateral locations or did not differ $(P=0.13$ for contralateral locations $)$ from $50 \%$ and for single-ovulating cows with older CL did not differ $(P=0.44$ for ipsilateral or $P=0.45$ for contralateral locations) by applying a z-statistic with a null hypothesis of $50 \%$. 


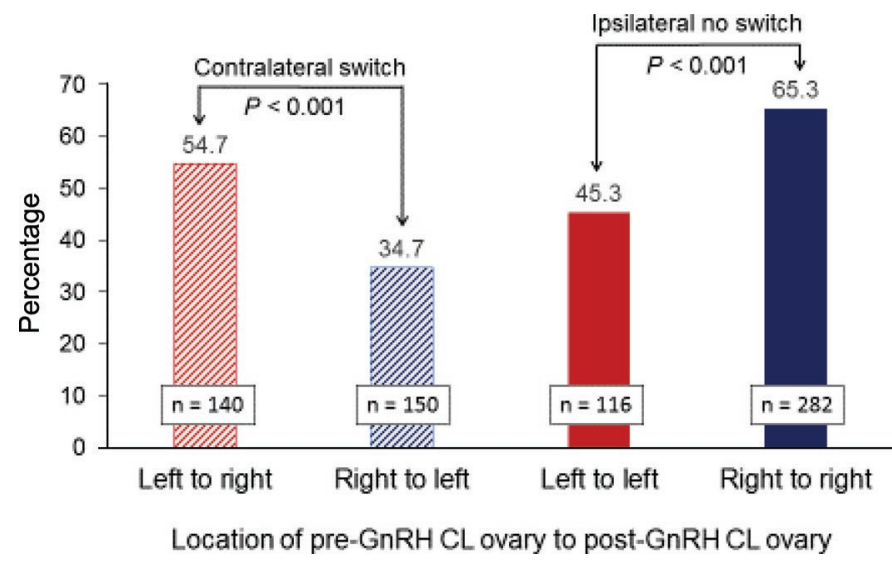

Figure 1. Ovary location of the GnRH-induced corpus luteum (CL) relative to $\mathrm{CL}$ present before $\mathrm{GnRH}$ treatment in lactating dairy cows. Results include cows exposed to GnRH-1 at the onset of Ovsynch and those exposed to GnRH-2 administered $56 \mathrm{~h}$ after $\mathrm{PGF}_{2 \alpha}$. No differences were detected for relative locations after either GnRH treatment so data were combined. Switching of successive CL contralaterally from left (before $\mathrm{GnRH}$ ) to right (after $\mathrm{GnRH}$ ) ovaries was more $(P<0.001)$ common than from right to left. The new CL on right ovaries were detected more $(P<0.001)$ frequently ipsilaterally right (before $\mathrm{GnRH}$ ) to right (after $\mathrm{GnRH}$ ) than for left to left.

and progesterone concentration were greater $(P \leq 0.05)$ when a CL was detected in both ovaries compared with a single CL detected in either the right or left ovary.

Switching ovary location of CL dominance from before to after GnRH-1 or GnRH-2 treatments differed between ovaries. Switching of the CL-ovary contralaterally from left (before GnRH) to right (after GnRH) was more $(P<0.001)$ common than switching from right to left (Figure 1). Furthermore, when CL-ovary dominance did not change after $\mathrm{GnRH}$, it remained ipsilateral right (before $\mathrm{GnRH}$ ) to right (after $\mathrm{GnRH}$ ) more $(P<0.001)$ often than left to left (Figure 1$)$. This relationship was similar in response to either GnRH-1 or GnRH-2 treatment and reinforces the greater activity of the right compared with the left ovary.

\section{Luteolysis and Age of Corpus Luteum}

Progesterone concentrations were related to age and number of $\mathrm{CL}$ before $\mathrm{PGF}_{2 \alpha}$ treatment for cows having both younger $\mathrm{CL}+$ older $\mathrm{CL}$ at the time of $\mathrm{PGF}_{2 \alpha}$ treatment compared with cows having only younger or only older CL (Table 6). Based on a cut point of $<0.5$ $\mathrm{ng} / \mathrm{mL}$ at $48 \mathrm{~h}$ after $\mathrm{PGF}_{2 \alpha}$, the proportion of cows with only older $\mathrm{CL}$ had greater $(P<0.05)$ luteolytic risk than cows bearing only younger CL or younger CL + older CL; the latter $2 \mathrm{CL}$ categories also differed ( $P$ $\leq 0.05$ ) from one another (Table 6).

The largest single or largest co-dominant follicle tended $(P=0.08)$ to be greater in cows bearing only a new CL (exposed to less progesterone during maturation) compared with cows bearing only older CL or younger CL + older CL. The second largest co-dominant follicle was also greater $(P \leq 0.05)$ in diameter for cows bearing only younger CL compared with cows having only older CL and tended $(P=0.08)$ to be greater than that in cows with both CL types (Table 6). Single-ovulation risk after GnRH-2 did not differ among CL age classes, but multiple-ovulation risk was

Table 5. Location of corpora lutea (CL) at the time of GnRH-1 and $\mathrm{PGF}_{2 \alpha}$ treatments during Ovsynch with number of CL per cow, progesterone concentration before $\mathrm{GnRH}$ treatments, and subsequent ovulation risk ${ }^{1}$

\begin{tabular}{|c|c|c|c|c|c|c|}
\hline Timing and ovary & $\begin{array}{l}\text { Cows } \\
\text { (no.) }\end{array}$ & $\begin{array}{c}\text { CL location } \\
(\%)\end{array}$ & $\begin{array}{l}\text { CL per } \\
\text { cow (no.) }\end{array}$ & $\begin{array}{l}\text { Progesterone } \\
\quad(\mathrm{ng} / \mathrm{mL})\end{array}$ & \multicolumn{2}{|c|}{ Ovulation risk ${ }^{3}$} \\
\hline Left & 214 & $34.8(41.4)$ & $1.2 \pm 0.03^{\mathrm{a}}$ & $3.7 \pm 0.2^{\mathrm{a}}$ & $67.3^{\mathrm{a}}$ & $16.5^{\mathrm{a}}$ \\
\hline Right & 303 & $49.4(58.6)$ & $1.2 \pm 0.02^{\mathrm{a}}$ & $3.7 \pm 0.1^{\mathrm{a}}$ & $60.7^{\mathrm{ab}}$ & $12.4^{\mathrm{a}}$ \\
\hline Both & 97 & 15.8 & $2.2 \pm 0.05^{\mathrm{b}}$ & $5.0 \pm 0.2^{\mathrm{b}}$ & $54.6^{\mathrm{b}}$ & $8.8^{\mathrm{a}}$ \\
\hline Left & 150 & $21.6(33.6)$ & $1.5 \pm 0.06^{\mathrm{a}}$ & $5.8 \pm 0.3^{\mathrm{a}}$ & $94.7^{\mathrm{a}}$ & $19.7^{\mathrm{a}}$ \\
\hline Right & 297 & $42.8(66.4)$ & $1.5 \pm 0.04^{\mathrm{a}}$ & $5.3 \pm 0.2^{\mathrm{a}}$ & $92.6^{\mathrm{a}}$ & $21.4^{\mathrm{a}}$ \\
\hline Both & 247 & 35.6 & $2.4 \pm 0.05^{\mathrm{b}}$ & $6.8 \pm 0.2^{\mathrm{b}}$ & $95.5^{\mathrm{a}}$ & $22.0^{\mathrm{a}}$ \\
\hline
\end{tabular}

\footnotetext{
${ }^{\mathrm{a}, \mathrm{b}}$ Means within column and GnRH treatment with different superscripts differ $(P<0.05)$.

${ }^{1}$ Least squares means \pm SEM where appropriate.

${ }^{2}$ Proportions in parentheses within GnRH treatment for single-ovulating cows differ from $50 \%(P \leq 0.01)$ by applying a z-statistic with a null hypothesis of $50 \%$.

${ }^{3}$ Proportion of cows that ovulated once (single). Multiple ovulation is the number of cows with $>1$ CL as a proportion of all ovulating cows.

${ }^{4}$ Ovulation risk to GnRH-1.

${ }^{5}$ Ovulation risk to GnRH-2 after $\mathrm{PGF}_{2 \alpha}$ treatment.
} 
Table 6. Characteristics of corpora lutea $(\mathrm{CL})$ at the time of $\mathrm{PGF}_{2 \alpha}$ treatment and concentrations of progesterone at 0 and $48 \mathrm{~h}$ thereafter including preovulatory follicle diameters, luteolytic risk, and subsequent ovulation and pregnancy risks

\begin{tabular}{|c|c|c|c|}
\hline \multirow[b]{2}{*}{ Item } & \multicolumn{3}{|c|}{ CL age class ${ }^{1}$} \\
\hline & Younger CL & Older CL & Younger CL + older CL \\
\hline CL per cow (no.) & $1.1 \pm 0.08^{\mathrm{a}}$ & $1.3 \pm 0.04^{\mathrm{b}}$ & $2.2 \pm 0.03^{\mathrm{c}}$ \\
\hline \multicolumn{4}{|l|}{ Progesterone $^{2}(\mathrm{ng} / \mathrm{mL})$} \\
\hline $0 \mathrm{~h}$ & $3.4 \pm 0.3^{\mathrm{a}}$ & $6.2 \pm 0.2^{\mathrm{b}}$ & $7.0 \pm 0.1^{\mathrm{c}}$ \\
\hline $48 \mathrm{~h}$ & $0.8 \pm 0.11^{\mathrm{a}}$ & $0.3 \pm 0.06^{\mathrm{b}}$ & $0.4 \pm 0.05^{\mathrm{b}}$ \\
\hline Second co-dominant follicle (mm) & $12.7 \pm 0.4^{\mathrm{a}, \mathrm{A}}$ & $11.3 \pm 0.4^{\mathrm{b}}$ & $11.9 \pm 0.2^{\mathrm{b}, \mathrm{B}}$ \\
\hline Single ovulation risk after GnRH (\%) & $91.7^{\mathrm{a}}$ & $93.4^{\mathrm{a}}$ & $94.3^{\mathrm{a}}$ \\
\hline Multiple ovulation risk after GnRH (\%) & $39.4^{\mathrm{a}}$ & $13.4^{\mathrm{b}}$ & $19.6^{\mathrm{b}}$ \\
\hline Post-AI luteal tissue volume ${ }^{3}\left(\mathrm{~cm}^{3}\right)$ & $7.9 \pm 0.4^{\mathrm{a}}(479)$ & $5.5 \pm 0.2^{\mathrm{b}}(68)$ & $5.6 \pm 0.2^{\mathrm{b}}(52)$ \\
\hline Post-AI progesterone $^{3}(\mathrm{ng} / \mathrm{mL})$ & $3.9 \pm 0.2^{\mathrm{a}}(292)$ & $2.9 \pm 0.1^{\mathrm{b}}(46)$ & $3.1 \pm 0.12^{\mathrm{b}}(42)$ \\
\hline Pregnancy/AI $32 \mathrm{~d}$ after $\mathrm{AI}^{4}(\%)$ & $26.4^{\mathrm{a}}(72)$ & $39.4^{\mathrm{b}, \mathrm{A}}(213)$ & $46.8^{\mathrm{b}, \mathrm{B}}(363)$ \\
\hline Pregnancy/AI $60 \mathrm{~d}$ after $\mathrm{AI}^{4}(\%)$ & $23.6^{\text {a }}(72)$ & $33.3^{\mathrm{a}}(213)$ & $43.5^{\mathrm{b}}(363)$ \\
\hline
\end{tabular}

${ }^{\mathrm{a}-\mathrm{c}}$ Means within row with different superscripts differ $(P<0.05)$.

${ }^{\mathrm{A}, \mathrm{B}}$ Means within row with different superscripts tended to differ $(P=0.08)$.

${ }^{1}$ Least squares means \pm SEM where appropriate.

${ }^{2}$ At 48 h after $\mathrm{PGF}_{2 \alpha}$ treatment.

${ }^{3}$ Assessed on d 6 after AI. Number of cows (in parentheses) differ because not all studies assessed progesterone concentration 6 d after AI.

${ }^{4}$ Number of cows (in parentheses) differed from total because of culling before pregnancy diagnosis occurred.

2.0 and 2.9 times greater $(P \leq 0.05)$ in cows bearing only younger $\mathrm{CL}$ at $\mathrm{PGF}_{2 \alpha}$ treatment compared with cows bearing both CL types and those bearing only older CL, respectively (Table 6).

Subsequent pregnancy per AI at $32 \mathrm{~d}$ after AI tended $(P=0.08)$ to be or was greater $(P \leq 0.05)$ for cows with both CL types compared with cows with only older CL or only younger CL, respectively (Table 6 ). Pregnancy per $\mathrm{AI}$ at $60 \mathrm{~d}$ after $\mathrm{AI}$ was greater $(P \leq 0.05)$ for cows that had both CL types before $\mathrm{PGF}_{2 \alpha}$ treatment compared with cows having only older or younger CL, respectively, partly because pregnancy loss tended $(P=$ 0.08 ) to be greater for cows having only younger CL or only older CL before timed AI (Table 6).

\section{Ovary Source of Oocyte-Embryo and Calf Sex}

Based on single pregnancies in this study, the percentage of female calves born resulting from eggs produced by left or right ovaries and carried in left or right uterine horns, respectively, did not differ between horns (Figure 2). Furthermore, the percentage of females resulting from first or repeat inseminations did not differ (Figure 2) when mean days from calving to conception differed $(P<0.001)$ for first and repeat services $(72$ vs. $160 \pm 2 \mathrm{~d}$, respectively).

A tendency $(P=0.14)$ for an interaction, however, was detected between horn of pregnancy and time when pregnancy occurred. More heifers conceived from right ovary-derived oocytes than from left ovary-derived oocytes (i.e., more females carried in right than left horns) when conception occurred after first AI services. In contrast, the opposite was observed for cows that conceived at repeat AI services (i.e., fewer females carried in the right than left horn; Figure 3). Although gestation duration was shorter $(P=0.01)$ for primiparous than multiparous cows $(276.2$ vs. $278.0 \pm$ $0.5 \mathrm{~d})$, no difference in gestation duration was detected

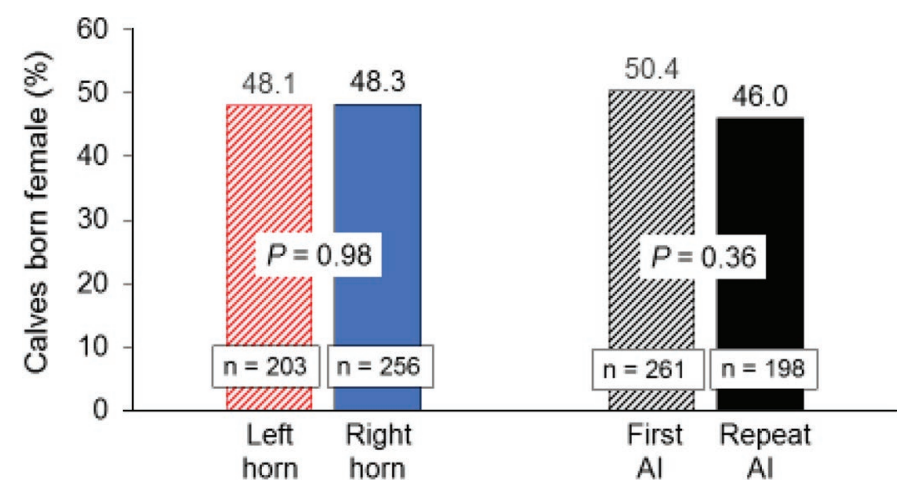

Figure 2. Percentage of female calves born that were carried in either the right or left uterine horn and percentage of female calves born resulting from first or repeat AI services. Neither of the proportions of females carried in left or right horns differed from $50 \%$ (z-statistic test; left: $P=0.59$ or right: $P=0.59)$ nor proportions of females born after first or repeat AI (z-statistic test; first: $P=0.90$ or repeat: $P=0.26$ ). 
for pregnancies carried in either horn or after shorter or longer DIM at conception.

\section{DISCUSSION}

The first and second objectives were to determine absolute and relative spatial location of CL and dominant follicles before and after exposure to $\mathrm{GnRH}$, and their spatial relation to new GnRH-1-induced CL or older CL. The present results confirm that the right ovary in the lactating dairy cow is dominant and more active than the left ovary (Tables 1 and 5), similar to a previous report for follicle location in cattle (Pineda, 1989). Right-ovary dominance was recently reported in dairy cows after GnRH-2 (Baez et al., 2017; Martins et al., 2018).

The majority of cows in the present study had experienced postpartum estrous cycles before exposure to the presynchronization and timed AI regimens. More than $90 \%$ of first postpartum ovulations in dairy cows occur in the ovary contralateral to the previously gravid horn, and $60 \%$ occur contralaterally between 15 and 20 d postpartum (Marion and Gier, 1968). This phenomenon is true in beef and dairy cattle, with greater tendencies for that relationship in dairy cattle and a lesser tendency in dairy cattle for contralateral dominance as days postpartum increase (Foote and Petersen, 1968). Furthermore, fertility was reportedly greater when ovulation occurred from the contralateral ovary (Gereš et al., 2011), probably because the contralateral uterine horn had reclaimed its prepregnant size and function sooner than the previously gravid horn. Right-horn



Figure 3. A tendency for more female calves born resulting from right ovary-derived oocytes at first services (carried in the right compared with left horns) compared with fewer right than left pregnancies for cows conceiving at repeat AI services. Neither of the proportions of females carried in left or right horns after first AI differed from $50 \%$ (z-statistic test; left: $P=0.50$ or right: $P=0.34$ ) nor did proportions of females carried in left or right horns after repeat AI (z-statistic test; left: $P=0.91$ or right: $P=0.11$ ). pregnancies were found more often than left-horn pregnancies in $57.4 \%$ of 2,300 Holstein-Friesian cows (Gereš et al., 2011).

To our knowledge, little information is available about differences in ovary dominance when the ovary is exposed to exogenous hormones. More active CL were found on right ovaries in Holstein-Friesian dairy cows before administration of $\mathrm{PGF}_{2 \alpha}$, and after its administration, $61 \%$ of CL were found in the right ovary (Karamishabankareh et al., 2015). Furthermore, in that study, no differences in the risks of estrus detection, pregnancy, or embryo survival were reported in 1,284 dairy cows when ovulation occurred from right or left ovaries. Ovulation and pregnancy risks did not differ between ovaries in the present study after timed AI, which corroborates previous observations in the bovine when AI was based on estrus (Gereš et al., 2011; Karamishabankareh et al., 2015).

Subsequent to $\mathrm{PGF}_{2 \alpha}$ administration and a positive pregnancy diagnosis at $28 \mathrm{~d}$ post-AI in cows bearing CL in the right ovary before $\mathrm{PGF}_{2 \alpha}, 66 \%$ ovulated contralaterally in the left ovary, and of those bearing CL in the left ovary, more than $80 \%$ ovulated contralaterally from the right ovary (Karamishabankareh et al., 2015). Present results confirm these findings (Figure 1) but to a lesser magnitude.

Although side of ovulation had no effect on pregnancy outcome in the previous study of 180 pregnancies produced after estrus and AI (Karamishabankareh et al., 2015 ), the right uterine horn carried more male fetuses $(61.8 \%)$ and left horns more female fetuses $(60.2 \%)$, with $56.7 \%$ carried in the right horn. Results from the present study after timed AI did not corroborate the previous data in which the tendency was for more female calves to be carried in right horns for first-service pregnancies and more females carried in left horns for repeat-service pregnancies. Cows in the previous and present studies were examined at comparable DIM $(>60)$, but other differences including milk yield $(9,730$ vs. $>14,000 \mathrm{~kg}$ ), breed (Holstein-Friesian vs. Holstein), ovulation synchronization (only $\mathrm{PGF}_{2 \alpha}$ vs. Ovsynch), insemination (estrus vs. timed AI) existed between studies (Karamishabankareh et al., 2015 vs. the present study, respectively).

Explanations for right-dominated ovulations in ruminants often included the proximity of the left ovary to the rumen and other extrinsic factors such as temperature or pressure fluctuations and mechanical contractions of the rumen (Pineda, 1989). Evidence to indicate some intrinsic differences between ovaries is substantiated by the fact that right ovary-retrieved oocytes from dairy cows subsequently fertilized and matured in vitro had greater risks for cleavage (88.1 vs. $73.3 \%$ ) and 
blastocyst (41.6 vs. $20.9 \%$ ) formation than left ovaryderived oocytes, respectively (Karamishabankareh et al., 2015). Similar observations have been reported in both fertile and infertile women (2,772 natural cycles) in which the fertility potential of oocytes from the right ovary surpassed that of the left ovary (Fukuda et al., 2000). Therefore, unequal activity between ovaries also may be related to greater oocyte competence and developmental potential of right ovary-derived oocytes.

The dominant follicle for single-ovulating cows in the present study tended to be more often located ipsilateral than contralateral to the CL before GnRH-1 was administered, whereas ovulation risk of the dominant follicle in response to $\mathrm{GnRH}$ did not differ between ovaries (Table 3). When age of CL was considered in the present study, preovulatory follicles tended to be more often detected ipsilateral than contralateral to younger than older CL before $\mathrm{PGF}_{2 \alpha}$ administration, with no differences for the frequency of ipsilateral versus contralateral-located preovulatory follicles for older CL (Table 4). Perhaps less spatial volume for development of the preovulatory follicle ipsilateral to larger and older CL compared with younger and smaller CL accounts for this lesser tendency.

Incidence of multiple ovulations in cows that had only GnRH-induced younger CL at the time of $\mathrm{PGF}_{2 \alpha}$ administration was associated with larger preovulatory follicles, lesser progesterone during which time the preovulatory follicle developed and matured, lesser luteolytic risk, and subsequent poorer fertility compared with cows bearing only older CL or both younger and older CL (Table 6). Cows with older CL in the latter group, whose preovulatory follicles were exposed to more progesterone during the period of follicular development before $\mathrm{PGF}_{2 \alpha}$-induced luteolysis, had greater pregnancy risk. Progesterone is critical to uterine function and plays important roles in modulating amino acids in the histotroph, a potentially critical factor for early embryonic or conceptus survival (Mullen et al., 2014). Furthermore, temporarily decreasing progesterone after AI decreased embryonic growth during early pregnancy in lactating dairy cows (Carvalho et al., 2017) and expression of interferon-tau-stimulated genes and progesterone concentration were greater in pregnant cows compared with those with early embryonic death (Sheikh et al., 2018).

Despite the greater CL size and progesterone concentration $6 \mathrm{~d}$ after $\mathrm{AI}$ in cows that bore only younger CL, pregnancy risk was compromised compared with that of cows having smaller preovulatory follicles that matured in a greater progesterone milieu after GnRH-1 and before GnRH-2 (Table 6). Lesser concentrations of progesterone during follicular maturation is associated with a greater frequency of LH pulses and explain the larger preovulatory follicles because of their increased growth rate (Sirois and Fortune, 1990) and its association with co-dominance and multiple ovulations. The larger follicles of the younger CL-bearing cows exposed to less progesterone during preovulatory follicular development may have led to conditions consistent with a persistent follicle that is associated with premature resumption of meiosis and a greater incidence of embryonic death between the 2- and 16-cell stages (Inskeep, 2004). Other potential mechanisms accounting for greater double ovulations in dairy cattle such as co-dominance during selection, older and more milkproductive cows, and hepatic steroid metabolism have been reviewed (Wiltbank et al., 2000).

In contrast to the present results, ovarian follicles were larger in ewes when found ipsilateral to the CL (Dufour et al., 1972). In cattle, several studies have found a positive CL-follicle intra-ovarian relationship during the estrous cycle not exposed to exogenous hormonal stimulation (Matton et al., 1981; Maurasse et al., 1985; Pierson and Ginther, 1987), but not in other studies (Ireland et al., 1979; Ginther et al., 1989). An interaction of the follicle with the CL was demonstrated in spontaneously cycling heifers. The dominant follicle of the first follicular wave grew more slowly and reached maximal diameter later in heifers that subsequently developed an ipsilateral 2-wave follicle-CL relationship compared with heifers having a contralateral 2- or 3-wave relationship (Ginther et al., 2013). Heifers with contralateral versus ipsilateral relationships had longer interovulatory intervals (prolonged postovulatory luteal phase and greater progesterone concentration), suggesting the absence of a negative intra-ovarian effect of the follicle on the CL. These intra-ovarian relationships of follicles and CL may be mediated by intra-ovarian substances, of which estradiol is a prime candidate (Ginther et al., 2013).

The third objective was to determine whether the ovary location of the younger CL relative to the older $\mathrm{CL}$ influenced luteolytic risk in response to $\mathrm{PGF}_{2 \alpha}$ treatment. As previously demonstrated (Stevenson, 2016a; Stevenson et al., 2018), younger CL in the presence of an older CL undergo luteolysis at a faster rate (progesterone decreases more quickly after $\mathrm{PGF}_{2 \alpha}$ treatment) than when only younger CL are present in ovaries at the time of $\mathrm{PGF}_{2 \alpha}$ treatment (Table 6). When cows had both younger and older CL, the proportion of those cows with progesterone $<0.5 \mathrm{ng} / \mathrm{mL}$ $48 \mathrm{~h}$ after $\mathrm{PGF}_{2 \alpha}$ was less than those bearing only older $\mathrm{CL}$, perhaps indicating that rate of luteolysis or progesterone decrease was likely inhibited by the presence of younger CL in the presence of older CL. Cows were less 
likely to conceive to timed AI when complete luteolysis of all luteal structures in response to $\mathrm{PGF}_{2 \alpha}$ failed to occur, as evidenced by not achieving concentrations of progesterone $<0.3$ to $0.5 \mathrm{ng} / \mathrm{mL}$ at timed AI or $72 \mathrm{~h}$ after $\mathrm{PGF}_{2 \alpha}$ (Santos et al., 2010; Ribeiro et al., 2012; Wiltbank et al., 2015).

Successful luteolysis of younger CL is also consistent with the report that hCG-induced luteal structures or $\mathrm{CL}$ on $\mathrm{d} 10$ of the estrous cycle were responsive to $\mathrm{PGF}_{2 \alpha}$ when younger $\mathrm{CL}$ (hCG-induced luteal structures) less than $5 \mathrm{~d}$ old were in the presence of older CL (Howard and Britt, 1990). In that study, the authors concluded that CL induced by treatment with $\mathrm{hCG}$ on $\mathrm{d} 10$ of the estrous cycle regress after exogenous $\mathrm{PGF}_{2 \alpha}$ by 2 $\mathrm{d}$ after ovulation, whereas spontaneously formed CL respond to $\mathrm{PGF}_{2 \alpha}$ only after $5 \mathrm{~d}$. Regression of younger CL in the presence of a more mature CL is intriguing because high-affinity $\mathrm{PGF}_{2 \alpha}$ receptors were identified in CL recovered from plasma membranes of CL of heifers on $\mathrm{d} 2,4,6$, or 10 (d $0=$ ovulation), suggesting that the reported lack of responsiveness to $\mathrm{PGF}_{2 \alpha}$ in the early younger CL may not be attributed to a deficiency of high-affinity $\mathrm{PGF}_{2 \alpha}$ receptors (Wiltbank et al., 1995). One avenue by which younger CL regress more successfully in the presence of a more mature CL could be attributed to the luteal oxytocin enhancement of uterine $\mathrm{PGF}_{2 \alpha}$ secretion generated by larger and more mature CL, thus inhibiting progesterone synthesis via a low-sensitivity state of the $\mathrm{PGF}_{2 \alpha}$ receptor and, at the same time, release of more oxytocin in a closed loop fashion (McCracken, 1998).

Contrary to the hypothesis presented, neither progesterone concentration nor luteolytic risk differed when younger CL were either ipsilateral or contralateral to older CL. Furthermore, the rate at which luteolysis progressed (measured by the proportion of cows with progesterone $<0.5 \mathrm{ng} / \mathrm{mL}$ at $48 \mathrm{~h}$ after $\mathrm{PGF}_{2 \alpha}$ ) may involve the preovulatory follicle. Location of co-dominant follicles during the luteolytic process affected the decrease in progesterone because proportionally fewer cows with co-dominant follicles in both ovaries had concentrations of progesterone $<0.5 \mathrm{ng} / \mathrm{mL}$ by $48 \mathrm{~h}$ after $\mathrm{PGF}_{2 \alpha}$ compared with cows bearing co-dominant follicles only in either right or left ovaries (Table 2).

When younger CL were present and preovulatory follicles were either ipsilateral or ipsilateral and contralateral to older CL, the rate of progesterone decrease tended to increase, indicating the possible spatial importance of maturing follicles and regressing CL in both ovaries. These relationships could be explained by blood flow to the CL-bearing ovary being greater than that to the non-CL-bearing ovary and its increase as the CL matures (Ford, 1982) or by apparent angio- coupling between ipsilateral dominant follicles and CL (Ginther et al., 2014). Furthermore, blood flow to the preovulatory follicle increases during proestrus and is attenuated by greater heat stress (Honig et al., 2016). Thus, delivery of exogenous $\mathrm{PGF}_{2 \alpha}$ to induce luteolysis could be enhanced by increased blood flow to ovaries bearing both the preovulatory follicle and CL. Although diameters of preovulatory follicles relative to younger or older CL were not affected by their ipsilateral or contralateral relation to CL in the present study, during the luteal phase in heifers, the size of each dominant follicle and CL and percentage of color Doppler signals of blood flow of each structure are greater when the dominant follicle and CL are in the same ovary and adjacent to each other than when separated. (Ginther et al., 2016). Thus, a positive relationship from preovulatory follicle to CL was tentatively indicated by a greater percentage of blood-flow signals in the CL when the 2 structures were ipsilateral (Ginther et al., 2016). It has been suggested that a paracrine interaction of estradiol, oxytocin, and $\mathrm{PGF}_{2 \alpha}$ may occur within the primate ovary to promote luteolysis (Maas et al., 1992). Given these relationships and increased blood flow to CL- and preovulatory follicle-bearing ovaries when the preovulatory follicle was ipsilateral or ipsilateral and contralateral to older CL may explain a hastening of progesterone decrease during luteolysis.

In summary, we accept the first hypothesis that the frequency of right ovarian structures was more prevalent than left ovarian structures in the present study, both before and after GnRH treatments. When exposed to GnRH, more follicles in left ovaries ovulated contralaterally than right-ovary follicles and the reverse was true for right ovaries; fewer left-ovary follicles ovulated ipsilaterally than right-ovary follicles. Preovulatory follicles before $\mathrm{PGF}_{2 \alpha}$ tended to be detected more often ipsilateral than contralateral to $\mathrm{CL}$ induced by $\mathrm{GnRH}$, but were of equal frequency ipsilateral or contralateral to older CL present before GnRH-2. A tendency for calves born resulting from first AI services in early lactation indicated that more heifers were carried in right horns in contrast to the opposite (greater heifer frequency in left horns) when conception occurred at repeat AI later in lactation. The second hypothesis is supported by more CL identified in right than left ovaries before and after GnRH. After GnRH induction of ovulation, frequency of right-ovary CL was twice that found in left ovaries, mostly resulting from a doubling of co-dominant follicle ovulations found in both ovaries. The third hypothesis was rejected because although luteolytic risk was greater for cows bearing only older CL or older CL + younger CL compared with cows bearing only younger CL, luteolytic risk did not dif- 
fer regardless of ipsilateral or contralateral location of younger CL relative to older CL. Luteolytic risk was compromised in cows bearing only younger CL, and it was associated with larger ovulatory follicles that developed in a reduced progesterone milieu leading to 2 to 3 times more co-dominant follicle ovulation and lesser subsequent pregnancy risk than in cows with at least 1 older CL before $\mathrm{PGF}_{2 \alpha}$ treatment. Not only is the right ovary more active in producing more follicles and CL in dairy cows based on the present study of cows exposed to ovulation synchronization and timed AI, more fertilized oocytes harvested (fertilized and matured in vitro) from right ovaries eventually cleave and form blastocysts than those from left ovaries (Karamishabankareh et al., 2015).

\section{ACKNOWLEDGMENTS}

This is contribution number 19-078-J from the Kansas Agricultural Experiment Station, Manhattan. The author acknowledges former co-authors of the original data re-examined in this report: H. I. Mellieon Jr., S. L. Pulley, J. A. Sauls, L. G. D. Mendonça, and B. E. Voelz.

\section{REFERENCES}

Baez, G. M., E. Trevisol, R. V. Barletta, B. O. Cardoso, A. Ricci, J. N. Guenther, N. E. Cummings, and M. C. Wiltbank. 2017. Proposal of a new model for CL regression or maintenance during pregnancy on the basis of timing of regression of contralateral, accessory CL in pregnant cows. Theriogenology 89:214-225.

Carvalho, P. D., C. C. Consentini, S. R. Weaver, R. V. Barleta, L. L. Hernandez, and P. M. Fricke. 2017. Temporarily decreasing progesterone after timed artificial insemination decreased expression of interferon-tau stimulated gene 15 (ISG15) in blood leukocytes, serum pregnancy-specific protein B concentrations, and embryo size in lactating Holstein cows. J. Dairy Sci. 100:3233-3242.

Dufour, J., O. J. Ginther, and L. E. Casida. 1972. Intraovarian relationship between corpora lutea and ovarian follicles in ewes. Am. J. Vet. Res. 33:1145-1146.

Foote, W. D., and D. W. Petersen. 1968. Relationships between side of pregnancy and side of subsequent ovarian activities in beef and dairy cattle. J. Reprod. Fertil. 16:415-421.

Ford, S. P. 1982. Control of uterine and ovarian blood flow throughout the estrous cycle and pregnancy of ewes, sows and cows. J. Anim. Sci. 55(Suppl. 2):32-42.

Fukuda, M., K. Fukuda, C. Y. Andersen, and A. G. Byskov. 2000. Right-sided ovulation favours pregnancy more than left-sided ovulation. Hum. Reprod. 15:1921-1926.

Gereš, D., B. Ževrnjz, D. Žubčić, R. Zobel, B. Vulić, N. Staklarević, and K. Gracin. 2011. Asymmetrical functional activities of ovaries and tubular part of the reproductive organs of dairy cows. Vet. Arh. 81:187-198.

Ginther, O. J. 1976. Comparative anatomy of uteroovarian vasculature. Vet. Scope 20:3-17. Animal Science Image Gallery (Ginther). Accessed Aug. 1, 2018. https://www.animalimagegallery.org/.

Ginther, O. J., J. M. Baldrighi, M. A. Siddiqui, S. T. Bashir, and H. B. Rakesh. 2016. Mechanism for greater frequency of contralateral than ipsilateral relationships between corpus luteum and ovulatory follicle for wave 3 in heifers. Theriogenology 85:361-367.
Ginther, O. J., S. T. Bashir, V. G. Santos, and M. A. Beg. 2013. Contralateral ovarian location between the future ovulatory follicle and extant corpus luteum increases the length of the luteal phase and number of follicular waves in heifers. Theriogenology 79:1130-1138.

Ginther, O. J., J. P. Kastelic, and L. Knopf. 1989. Intraovarian relationships among dominant and subordinate follicles and the corpus luteum in heifers. Theriogenology 32:787-795.

Ginther, O. J., M. A. Siddiqui, J. M. Baldrighi, and M. M. Hoffman. 2014. Effect of intraovarian proximity between dominant follicle and corpus luteum on dimensions and blood flow of each structure in heifers. Theriogenology 82:875-883.

Honig, H., L. Ofer, M. Kaim, S. Jacobi, D. Shinder, and E. Gershon. 2016. The effect of cooling management on blood flow to the dominant follicle and estrous cycle length at heat stress. Theriogenology $86: 626-634$.

Howard, H. J., and J. H. Britt. 1990. Prostaglandin $\mathrm{F}_{2 \alpha}$ causes regression of an hCG-induced corpus luteum before day 5 of its lifespan in cattle. J. Reprod. Fertil. 90:245-253.

Inskeep, E. K. 2004. Preovulatory, postovulatory, and postmaternal recognition effects of concentrations of progesterone on embryonic survival in the cow. J. Anim. Sci. 82(E. Suppl.):E24-E39.

Ireland, J. J., P. B. Coulson, and R. L. Murphree. 1979. Follicular development during four stages of the estrous cycle of beef cattle. J. Anim. Sci. 49:1261-1269.

Karamishabankareh, H., H. Hajarian, M. Shahsavari, and R. Moradinejad. 2015. In vivo and in vitro study of the function of the left and right bovine ovaries. Theriogenology 84:724-731.

Maas, S., H. Jarry, A. Teichmann, W. Arth, W. Kuhn, and W. Wuttke. 1992. Paracrine actions of oxytocin, prostaglandin $\mathrm{F}_{2 \alpha}$, and oestradiol within the human corpus luteum. J. Clin. Endocrinol. Metab. $74: 306-312$.

Marion, G. B., and H. T. Gier. 1968. Factors affecting bovine ovarian activity after parturition. J. Anim. Sci. 27:1621-1626.

Martins, J. P. N., D. Wang, N. Mu, G. F. Rossi, A. P. Martini, V. R. Martins, and J. R. Pursley. 2018. Level of circulating concentrations of progesterone during ovulatory follicle development affects timing of pregnancy loss in lactating dairy cows. J. Dairy Sci. 101:10505-10525.

Matton, P., V. Adelakoun, Y. Couture, and J. J. Dufour. 1981. Growth and replacement of the bovine ovarian follicles during the estrous cycle. J. Anim. Sci. 52:813-820.

Maurasse, C., P. Matton, and J. J. Dufour. 1985. Ovarian follicular populations at two stages of an estrous cycle in heifers given high energy diets. J. Anim. Sci. 61:1194-1200.

McCracken, J. A. 1998. Luteolysis. Pages 1083-1094 in Encyclopedia of Reproduction. Vol. 3. E. Knobil and J. D. Neill, ed. Academic Press, New York, NY.

Momont, H. W., and B. E. Seguin. 1984. Influence of day of estrous cycle on response to PGF2 alpha products: Implication for AI programs for dairy cattle. Pages 336-338 in Proc. 10th Int. Congr. Anim. Reprod. AI. University of Illinois at Urbana-Champaign, Urbana, IL.

Mullen, M. P., F. W. Bazer, G. Wu, M. H. Parr, A. C. Evans, M. A. Crowe, and M. G. Diskin. 2014. Effects of systemic progesterone during the early luteal phase on the availabilities of amino acids and glucose in the bovine uterine lumen. Reprod. Fertil. Dev. $26: 282-292$.

Pierson, R. A., and O. J. Ginther. 1987. Follicular populations during the estrous cycle in heifers. I. Influence of day. Anim. Reprod. Sci. $14: 165-176$.

Pineda, M. H. 1989. Female reproductive system. Page 314 in Veterinary Endocrinology and Reproduction. L. E. McDonald and M. H. Pineda, ed. Lea \& Febiger, Philadelphia, PA.

Pulley, S. L., D. H. Keisler, and J. S. Stevenson. 2015. Concentrations of luteinizing hormone and ovulatory responses in dairy cows before timed artificial insemination. J. Dairy Sci. 98:6188-6201.

Ribeiro, E. S., R. S. Bisinotto, M. Favoreto, L. T. Martins, R. L. A. Cerri, F. T. Silvestre, L. F. Greco, W. W. Thatcher, and J. E. P. Santos. 2012. Fertility in dairy cows following presynchronization 
and administering twice the luteolytic dose of prostaglandin $\mathrm{F}_{2 \alpha}$ as one or two injections in the 5-day timed artificial insemination protocol. Theriogenology 78:273-284.

Santos, J. E., C. D. Narciso, F. Rivera, W. W. Thatcher, and R. C. Chebel. 2010. Effect of reducing the period of follicle dominance in a timed artificial insemination protocol on reproduction of dairy cows. J. Dairy Sci. 93:2976-2988.

Scanlon, P. F. 1972. Frequency of transuterine migration of embryos in ewes and cows. J. Anim. Sci. 34:791-794.

Sheikh, A. A., O. K. Hooda, A. Kalyan, A. Kamboj, S. Mohammed, M. Alhussien, S. Reddi, P. G. Shimray, A. Rautela, S. Pandita, S. Kapila, S. De, and A. K. Dang. 2018. Interferon-tau stimulated gene expression: A proxy to predict embryonic mortality in dairy cows. Theriogenology 120:61-67.

Sirois, J., and J. E. Fortune. 1990. Lengthening the bovine estrous cycle with low levels of exogenous progesterone: a model for studying ovarian follicular dominance. Endocrinology 127:916-925.

Stevenson, J. S. 2016a. Physiological predictors of ovulation and pregnancy risk in a fixed-time artificial insemination program. J. Dairy Sci. 99:10077-10092.

Stevenson, J. S. 2016b. Ovarian characteristics and timed artificial insemination pregnancy risk after presynchronization with go- nadotropin-releasing hormone 7 days before $\mathrm{PGF}_{2 \alpha}$ in dairy cows. Theriogenology 85:1139-1146.

Stevenson, J. S., S. L. Pulley, and H. I. Mellieon Jr.. 2012. Prostaglandin $\mathrm{F}_{2 \alpha}$ and gonadotropin-releasing hormone $\mathrm{GnRH}$ administration improve progesterone status, luteal number, and proportion of ovular and anovular dairy cows with corpora lutea before a timed AI program. J. Dairy Sci. 95:1831-1844.

Stevenson, J. S., J. A. Sauls, L. G. D. Mendonça, and B. E. Voelz. 2018. Dose-frequency of prostaglandin $\mathrm{F}_{2 \alpha}$ administration to dairy cows exposed to presynchronization and either five- or seven-day Ovsynch program durations: Ovulatory and luteolytic risks. J. Dairy Sci. 101:9575-9590.

Wiltbank, M. C., G. M. Baez, F. Cochrane, R. V. Barletta, C. R Trayford, and R. T. Joseph. 2015. Effect of a second treatment with prostaglandin $\mathrm{F}_{2 \alpha}$ during the Ovsynch protocol on luteolysis and pregnancy in dairy cows. J. Dairy Sci. 98:8644-8654.

Wiltbank, M. C., P. M. Fricke, S. Sangsritavong, R. Sartori, and O. J. Ginther. 2000. Mechanisms that prevent and produce double ovulations in dairy cattle. J. Dairy Sci. 83:2998-3007.

Wiltbank, M. C., T. F. Shiao, D. R. Bergfelt, and O. J. Ginther. 1995. Prostaglandin F2 alpha receptors in the early bovine corpus luteum. Biol. Reprod. 52:74-78. 